\title{
TOPOVI ALI MASLO? PRIMERJALNA ANALIZA OBRAMBNIH IZDATKOV REPUBLIKE SLOVENIJE
}

\section{GUNS VS. BUTTER? COMPARATIVE ANALYSIS OF SLOVENIA'S DEFENCE EXPENDITURE}

Povzetek Javnofinančne posledice gospodarske krize so večino držav članic zveze Nato vodile v bistveno zmanjšanje obrambnih izdatkov. Analiza je razkrila, da so v obdobju 2009-2015 obrambni izdatki Republike Slovenije padli najbolj med vsemi zaveznicami, ob tem pa je Slovenijo zaradi naraščajočega deleža izdatkov za osebje začela bremeniti vse bolj neuravnotežena struktura obrambne porabe. V prispevku sem potrdil domnevo o neustreznem kadrovskem obsegu slovenskih oboroženih sil glede na razpoložljive finančne vire. Analizo sem zasnoval na teoretično podkrepljeni premisi o vzročni povezanosti spremenljivk. S pomočjo bivariatne analize sem potrdil visoko pozitivno korelacijo med višino obrambnih izdatkov za osebje in kadrovskim obsegom oboroženih sil ter prek regresijske analize izsledke apliciral na načrtovano stanje slovenskega obrambnega sistema leta 2020. Ob tem sem ugotovil, da je neskladje med finančnimi viri in kadrovskim obsegom implicirano tudi v trenutno veljavnem srednjeročnem obrambnem programu in da doseganje kadrovskih in strukturno-finančnih ciljev ob predvideni stopnji rasti obrambnih izdatkov ni realno uresničljivo.

Ključne Obrambni izdatki, izdatki za osebje, kadrovski obseg oboroženih sil, Slovenska besede vojska, bivariatna analiza.

Abstract The effects of the economic crisis on public finances have led to significant reductions in defence spending in the majority of NATO member states. As revealed by the analysis of 2009-2015, the largest drop in defence expenditure occurred in the Republic of Slovenia, where a rising share of expenditure devoted to personnel led to an increased imbalance in the allocation of defence resources. In the article, I confirmed the hypothesis on inappropriate personnel strength of the Slovenian Armed Forces with regard to the available financial resources. I based the analysis on a theoretically supported premise about a causal relationship between variables. 
A bivariate analysis confirmed a strong positive correlation between the level of personnel expenditure and the overall personnel strength. Furthermore, I used a regression analysis to form an estimate on a 2020 desired end-state based on the acquired results. I concluded that the discrepancy between financial resources and the personnel strength is implied in the Medium-Term Defence Programme as well. I therefore assessed the currently valid medium term staff and financial structure goals as realistically unattainable.

\section{Key words Defence expenditure, personnel expenditure, armed forces personnel strength, Slovenian Armed Forces, bivariate analysis.}

Uvod V zadnjih letih je bilo v medijih zaslediti poročila o neprimerni višini in strukturi obrambnega proračuna Republike Slovenije. Po poročanju časnika Delo (Žerjavič, 2015) je bila Slovenija leta 2014 z 0,98 odstotka bruto domačega proizvoda (BDP), namenjenega za obrambo, v spodnji sredini držav članic Nata. Ob tem je bil posebej problematičen razrez proračuna, saj je Slovenija leta 2014 za naložbe namenila najmanjši delež proračuna $\mathrm{v}$ celotnem zavezništvu, le 0,66 odstotka. Predsednik Republike Slovenije - vrhovni poveljnik obrambnih sil - je v začetku leta 2016 ocenil, da je Slovenska vojska že tretje leto zapored na najnižji stopnji pripravljenosti, povprečna ocena za pripravljenost vojske za delovanje v krizi ali v vojni pa je bila opredeljena kot nezadostna. Predsednik je med vzroki izpostavil predvsem pomanjkanje finančnih sredstev (Masten, 2016). Skoraj enaka ocena je bila podana tudi leto pozneje (L. L., A. Č., 2017). Čeprav je Slovenija v preteklih letih največji delež obrambnega proračuna med vsemi članicami Nata namenjala plačam, je bilo zaslediti opozorila o slabšanju socialnega položaja vojakov (T. H., 2014; Eržen, 2015 in Škrjanc, 2016). Na nekonkurenčnost in neustrezno ovrednotenje vojaškega poklica je začela javno opozarjati tudi ministrica za obrambo Andreja Katič (Karba, 2016; L. L., A. Č., 2017).

Razumljivo je, da je zmanjševanje obrambnih izdatkov pritegnilo pozornost ne le medijev, temveč tudi znanstvene in strokovne srenje. Čeprav je problematiko v preteklih letih z različnih vidikov osvetlilo več avtorjev - med njimi Kotnik (2014, 2016), Potočnik (2015), Žurga (2016) in Young (2016) -, v literaturi ni zaslediti podrobnejše analize, $v$ kateri bi bila obravnavana izrazita strukturna neuravnoteženost slovenskih obrambnih izdatkov. Problematiko deloma obravnava Young (2016, str. 20-21), ki izpostavlja, da je upravljanje obrambnih resorjev nekdanjih komunističnih držav - torej tudi Slovenije - še vedno obremenjeno z zapuščino nekdanjih obrambnih konceptov. $\mathrm{V}$ teh resorjih denar še vedno ni razumljen kot najpomembnejše upravljavsko orodje, kar - ob pretirani centralizaciji procesa odločanja in nekoherentnosti obrambnih politik - vodi v porušenje ravnotežja obrambnih proračunov in posledično v razkroj obrambnih zmogljivosti. Young (2016, str. 21) opozarja, da je reševanje dolgoletne neuravnovešenosti zahtevno in »skoraj vedno« povezano z zmanjševanjem števila osebja ter spremenjenimi prioritetami namenjanja finančnih sredstev. 
Glede na navedeno domnevam, da Slovenijo bremeni neprimerno razmerje med višino obrambnih izdatkov in kadrovskim obsegom oboroženih sil (številom pripadnikov). Ob tem izhajam iz premise, da ima povišanje obrambnih izdatkov pozitiven vpliv na kadrovski obseg oboroženih sil (vzročna povezanost). Da bi preveril hipotezo, sem izvedel primerjalno analizo, pri čemer so me zanimali obrambni izdatki držav članic Nata, s poudarkom na prepoznavanju položaja Slovenije.

Preučevanje je potekalo $\mathrm{v}$ treh korakih. V prvi fazi sem problematiko obrambnih izdatkov Republike Slovenije umestil v širši kontekst in s teorijo podkrepil premiso o vzročni povezanosti obravnavnih spremenljivk. V drugi fazi sem s pomočjo bivariatne analize preveril domnevo o pozitivni povezanosti višine obrambnih izdatkov s kadrovskim obsegom oboroženih sil, v tretji pa prek regresijske analize ugotovitve apliciral na načrtovano stanje slovenskega obrambnega sistema leta 2020. Analiza temelji na podatkih za populacijo držav članic Nata v obdobju 2009-2015. ${ }^{1} \mathrm{~V}$ delih analize, ki se osredotočajo le na Slovenijo, sem analizo razširil na leto njenega vstopa v zavezništvo (2004). Da bi lahko primerjal različne države, sem analizo zasnoval na podatkih o obrambnih izdatkih, izraženih v deležu BDP. Če ni navedeno drugače, so podatki za izračune in analizo črpani iz uradnih letnih poročil zveze Nato (Nato, 2006; Nato, 2010 in Nato, 2016). Ob upoštevanju ugotovitev Younga (2016) sem dodatno pozornost namenil prepoznavanju razlik med postkomunističnimi in starejšimi članicami zavezništva.

\section{OBRAMBNI IZDATKI}

V literaturi, povezani s financiranjem obrambnega sistema, ${ }^{2}$ zasledimo več sorodnih sintagem, kot so obrambni izdatki, vojaški izdatki, obrambna poraba in obrambni proračun. Še posebej prva izmed navedenih terminov se tudi v strokovni in znanstveni literaturi pogosto uporabljata kot sinonima. ${ }^{3}$ Za ta prispevek je bistvena kategorija

\footnotetext{
Leto 2009 je bilo za večino držav članic zveze Nato zadnje leto, v katerem obrambnih izdatkov še niso bistveno krčile zaradi javnofinančnih rezov, povezanih z reševanjem globalne gospodarsko-finančne krize. To dokazuje tudi podatek o povprečnem deležu BDP za obrambne izdatke v državah članicah Nata, ki se v predkriznem obdobju (2006-2009) ni bistveno spreminjal in je bil leta 2009 pri 1,68 odstotka BDP. V naslednjih letih je sledil strm padec, najprej na 1,58 odstotka BDP leta 2010, leta 2011 na 1,5 odstotka BDP, v naslednjih štirih letih pa še nadaljnji padec za skupno 0,1 odstotne točke na povprečno 1,4 odstotka BDP. Podobno je padla tudi vrednost mediane - z 1,52 odstotka BDP leta 2009 na 1,16 odstotka BDP leta 2015. Tudi primerjava nominalnih zneskov kaže podobno sliko, saj so države članice Nata leta 2009 skupno za obrambne izdatke namenile 1072 milijard ameriških dolarjev, leta 2015 pa približno 19 odstotkov manj, tj. 867 milijard ameriških dolarjev (izračun temelji na stalnih cenah in menjalnih tečajih za leto 2010).

2 Po zapisu Grizolda (1999, str. 40) obrambni sistem predstavlja »celoto vojaških in nevojaških elementov (enot, ustanov, zmogljivosti, postopkov in norm) v nacionalnovarnostni strukturi, namenjeno za opravljanje obrambno-zaščitnih funkcij družbe«. Skladno z veljavno Resolucijo o strategiji nacionalne varnosti Republike Slovenije (2010) obrambni sistem v Sloveniji tvorijo »Slovenska vojska kot nosilka vojaške obrambe in razvoja vojaških zmogljivosti ter nevojaški deli obrambnega sistema [...]. Vobrambni sistem se z izvajanjem dejavnosti, ki prispevajo k obrambi države, vključujejo tudi drugi državni organi, organi lokalnih skupnosti ter civilnodružbene organizacije, ki so posebnega pomena za obrambo."

3 Na tem mestu velja posebej izpostaviti, da obrambnih izdatkov ne gre enačiti z obrambnim proračunom. Tako se v Sloveniji obrambni izdatki razlikujejo od realizacije finančnega načrta Ministrstva za obrambo v državnem proračunu, saj vključujejo tudi vojaške pokojnine in sredstva Urada za varovanje tajnih podatkov, ne vključujejo pa sredstev za sistem varstva pred naravnimi in drugimi nesrečami.
} 
obrambnih izdatkov, kot jih opredeljuje Nato, saj je analiza izvedena na podlagi Natovih poročil o obrambnih izdatkih držav članic. ${ }^{4}$ Strnem lahko, da se po Natovi definiciji v obrambne izdatke štejejo vsa vladna izplačila (1) oboroženim silam, ${ }^{5}$ (2) izplačila pokojnin vojaškemu osebju in civilnemu osebju vojaških oddelkov, (3) stroški za mirovne in humanitarne operacije, (4) stroški za uničevanje in nadzor uničevanja orožja, opreme in streliva, (5) stroški za raziskave in razvoj, (6) izdatki za vojaško komponento v mešanih civilno-vojaških aktivnostih, (7) donacije finančne pomoči zavezniškim državam in (8) izdatki za Natovo skupno infrastrukturo. Plačila vojne škode in izdatke za civilno obrambo Nato iz definicije izključuje (Nato, 2016, str. 10). Pomembno je izpostaviti še razčlenitev porazdelitve obrambnih izdatkov. Nato razlikuje med izdatki za (1) opremo, (2) osebje, (3) infrastrukturo in (4) drugimi izdatki (ki med drugim vključujejo operativne stroške in vzdrževanje).

Višina obrambnih izdatkov posamezne države je odvisna od številnih dejavnikov, še zlasti pa od strategije in ciljev nacionalnovarnostne politike na eni in splošnih prioritet državnega proračuna na drugi strani (Zorko, 2004, str. 8). Po besedah Stańczyka (2014, str. 313) se višina obrambnih izdatkov posamezne države pogosto uporablja kot kazalnik za ponazarjanje splošne operativne zmogljivosti njenih oboroženih sil, skokovito povišanje izdatkov v državi ali regiji pa kot opozorilnik na povišano verjetnost izbruha notranjih ali zunanjih konfliktov. $\mathrm{V}$ analizah je treba biti previden - kot implicira Walkerjeva (2014), podatek o obrambnih izdatkih ne daje informacije o učinkovitosti porabe sredstev niti o uspešnosti izpolnjevanja zadanih ciljev ali o primernosti višine financiranja glede na število in zmogljivosti potencialnih nasprotnikov (oziroma primernosti glede na vire ogrožanja, op. a.). Tudi pri analizi razreza obrambnih izdatkov je treba biti previden, saj iz sicer enostavnih in preglednih podatkov ne moremo neposredno sklepati o (bojni) moči oboroženih sil.

Države članice Nata so leta 2006 sprejele politično zavezo, da bodo za obrambne izdatke namenjale vsaj dva odstotka BDP na leto. S tem naj bi zmanjšale neskladje med obrambnimi izdatki Združenih držav Amerike na eni in preostalih držav članic na drugi strani ter poskrbele, da bi vse države članice za kolektivno obrambo namenjale razmeroma enakovreden delež sredstev. Kljub zavezam pa državam cilja ni uspelo doseči, saj so javnofinančne posledice gospodarske krize po letu 2009 vodile v dodatno zmanjšanje obrambnih izdatkov, ob čemer je začela naraščati tudi asimetrija izdatkov znotraj evropskega krila zavezništva. Zaveznice so se zato leta 2014 na vrhu v Walesu ponovno zavezale $\mathrm{k}$ postopnemu dvigu izdatkov na raven dveh odstotkov BDP. $\mathrm{V}$ desetletnem obdobju naj bi dosegle tudi, da bi vsaj petino sredstev vlagale v izdatke

\footnotetext{
Aktualne podatke in napovedi obrambnih izdatkov ministrstva za obrambo držav članic redno posredujejo zvezi Nato, ta pa podatke dopolni z ekonomskimi in demografskimi kazalniki, pridobljenimi od Evropske komisije in Organizacije za gospodarsko sodelovanje in razvoj ter izdela poročilo s prikazom ključnih ekonomskih in finančnih indikatorjev. Nato (2016, str. 1) opozarja na razlike med nacionalnimi definicijami in definicijami mednarodnih organizacij, zato lahko nekateri podatki znatno odstopajo od tistih, prikazanih v poročilih nacionalnih oblasti.

V Sloveniji edino komponento oboroženih sil predstavlja Slovenska vojska, saj v obrambnem sistemu ni oblikovanih drugih vojaških ali paravojaških elementov (kot so mejna straža, orožništvo, obalna straža ipd.), ki bi bili usposobljeni, opremljeni in predvideni za izvajanje oboroženega boja oziroma vojaške obrambe.
} 
za opremo, s čimer naj bi bili omogočeni ustrezna modernizacija sil, zmanjševanje razlik v zmogljivostih in interoperabilnosti med državami članicami ter krepitev evropske obrambne in tehnološke baze (Nato 2017). Slovenija deklarativno sprejema navedene cilje (2/20) in skladno s trenutno veljavnimi razvojno-usmerjevalnimi dokumenti (Resolucija o splošnem dolgoročnem programu razvoja in opremljanja Slovenske vojske do leta 2025, str. 29; Srednjeročni obrambni program 2016-2020, str. 6) napoveduje prizadevanja, da bo po letu 2017 postopoma poviševala obrambne izdatke in dolgoročno izpolnila politične zaveze do zavezništva.

\section{OBRAMBNI IZDATKI REPUBLIKE SLOVENIJE}

Slovenija je leta 2004, ko je vstopila v zvezo Nato, za obrambne izdatke namenila 1,43 odstotka BDP. Najvišji obrambni izdatki so bili ugotovljeni v letih 2009 in 2010, ko je bilo v ta namen realiziranih 1,59 oziroma 1,61 odstotka BDP. ${ }^{6}$ Zaradi javnofinančnih posledic, povezanih $\mathrm{z}$ nastopom gospodarske krize, je sledil strm padec - tako je Slovenija leta 2015 za obrambo namenila le še 0,94 odstotka BDP (graf 1). Žurga (2016, str. 40) o zavestni slabitvi izdatkov za celotni slovenski nacionalnovarnostni sistem, še zlasti pa za njegov obrambni del, govori kot o »novi sodobni grožnji nacionalni varnosti, in sicer proračunski«.

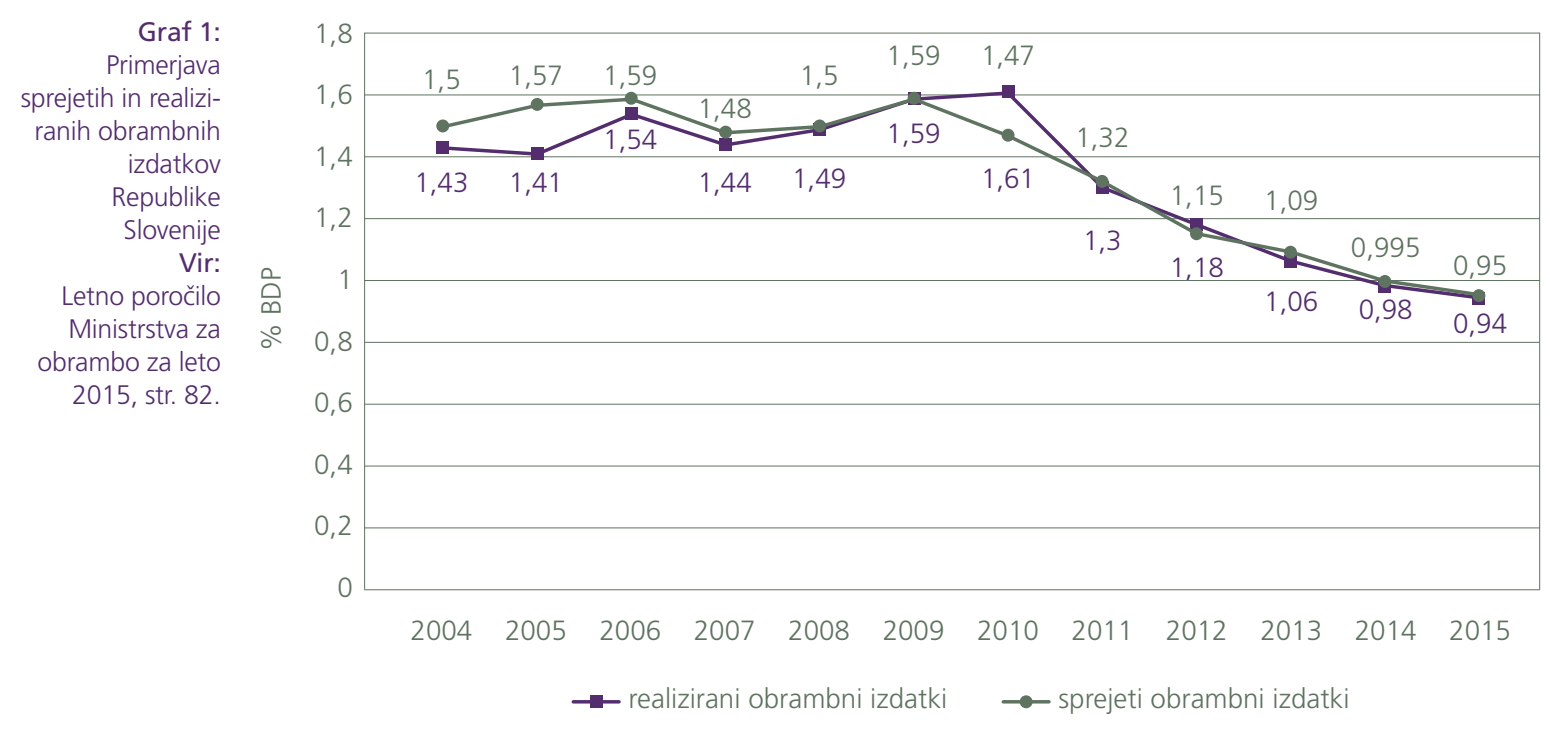

\footnotetext{
6 Leta 2010 je Republika Slovenija dobila vrnjen t. i. klirinški dolg, pri čemer je Ruska federacija Sloveniji dobavila vojaško večnamensko patruljno ladjo Triglav 11, 122 raket zemlja-zrak kratkega dosega Igla (SA24) in 15 lansirnih ploščadi, preostanek pa vrnila v denarju. Ladja, rakete in ploščadi so bili obračunani kot obrambni izdatek v opremo, zato so realizirani obrambni izdatki Republike Slovenije v letu 2010 za okoli 0,15 odstotne točke višji od predvidenih oziroma kot bi bili, če do vračila dolga ne bi prišlo (Letno poročilo Ministrstva za obrambo za leto 2010, str. 63).
} 
Podobno kot v Sloveniji je po začetku krize obrambne izdatke znižala tudi večina preostalih držav zavezništva - izdatki so padli povprečno za 14,4 odstotka. Če primerjam obrambne izdatke v letih 2009 in 2015, ugotovim, da so obrambne izdatke, izražene v deležu BDP, povišale le Estonija, Litva, Luksemburg, Poljska in Romunija, vse preostale države pa so delež BDP, namenjen obrambi, znižale. Pri tem je treba izpostaviti, da so obrambni izdatki v Sloveniji padli najbolj med vsemi državami članicami, tj. za skoraj 41 odstotkov (graf 2$)^{7}$

Graf 2:

Primerjava obrambnih izdatkov držav članic Nata (v deležu BDP) za leto 2015 glede na leto 2009 Vir: Lasten izračun po podatkih Nata (2016).

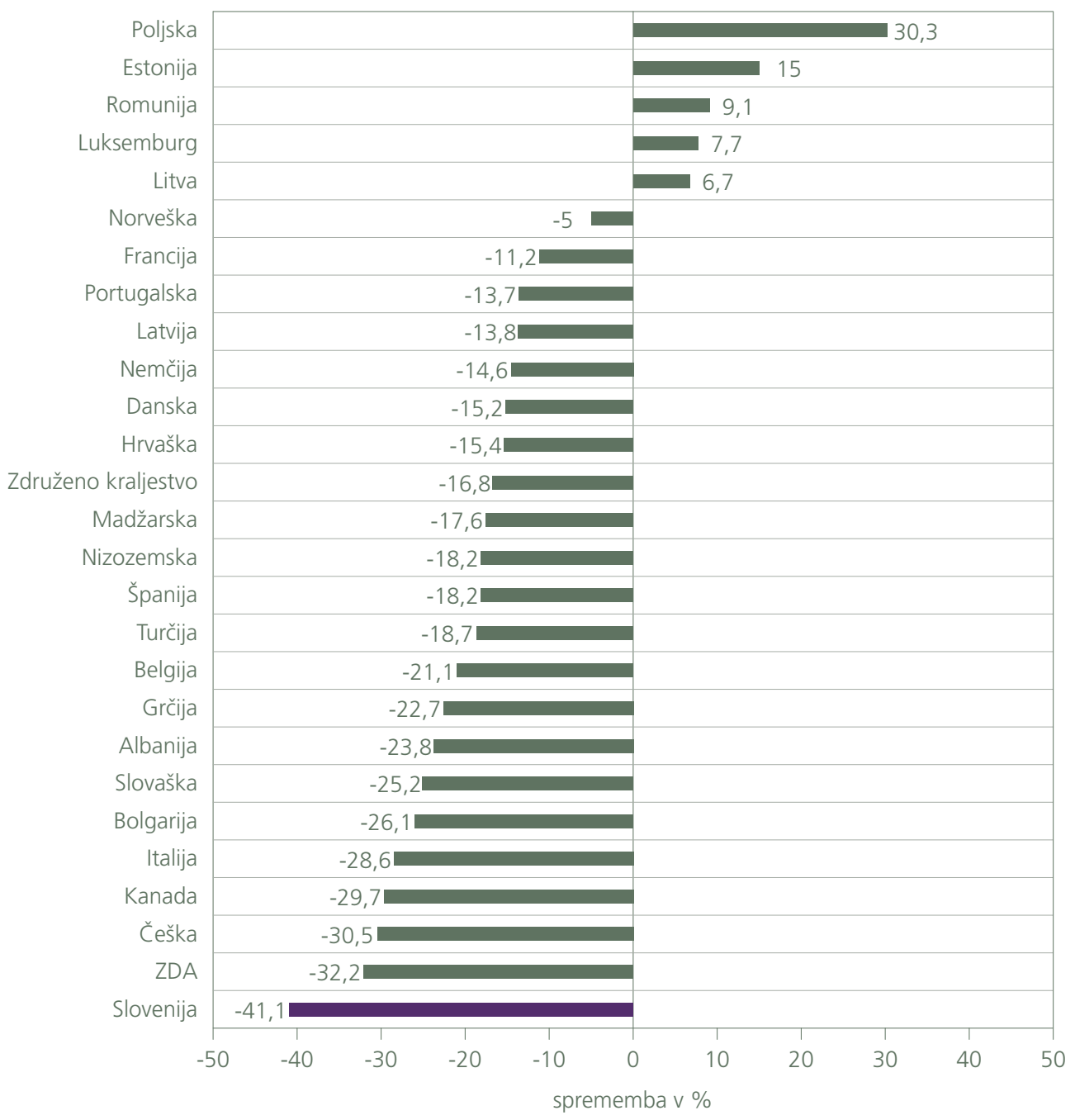

Zanimivo je, da so drugi največji padec obrambnih izdatkov v obravnavanem obdobju zaznale Združene države Amerike (ZDA). To je večinoma posledica umika njenih oboroženih sil iz dolgoletnih operacij v Afganistanu in Iraku, pa tudi rezultat avtomatskih proračunskih rezov, ki so začeli veljati leta 2013 (Stańczyk, 2014, str. 313). 
Slovenija je leta 2015 za obrambne izdatke namenila 0,94 odstotka BDP. Manjši delež BDP so za obrambo namenile le še Belgija, Luksemburg in Španija, enak odstotek kot Slovenija pa Madžarska. Natovo priporočilo dveh odstotkov so izpolnjevale le Estonija, Grčija, Poljska, Združeno kraljestvo in Združene države Amerike (graf 3). Članice Nata so sicer leta 2015 za obrambne izdatke namenile povprečno 1,4 odstotka BDP. Vrednost mediane je bila 1,16 odstotka BDP. ${ }^{8}$

Graf 3: Obrambni izdatki držav članic Nata leta 2015
Vir:
Lastna
ponazoritev po
podatkih Nata
$(2016$, str. 5).

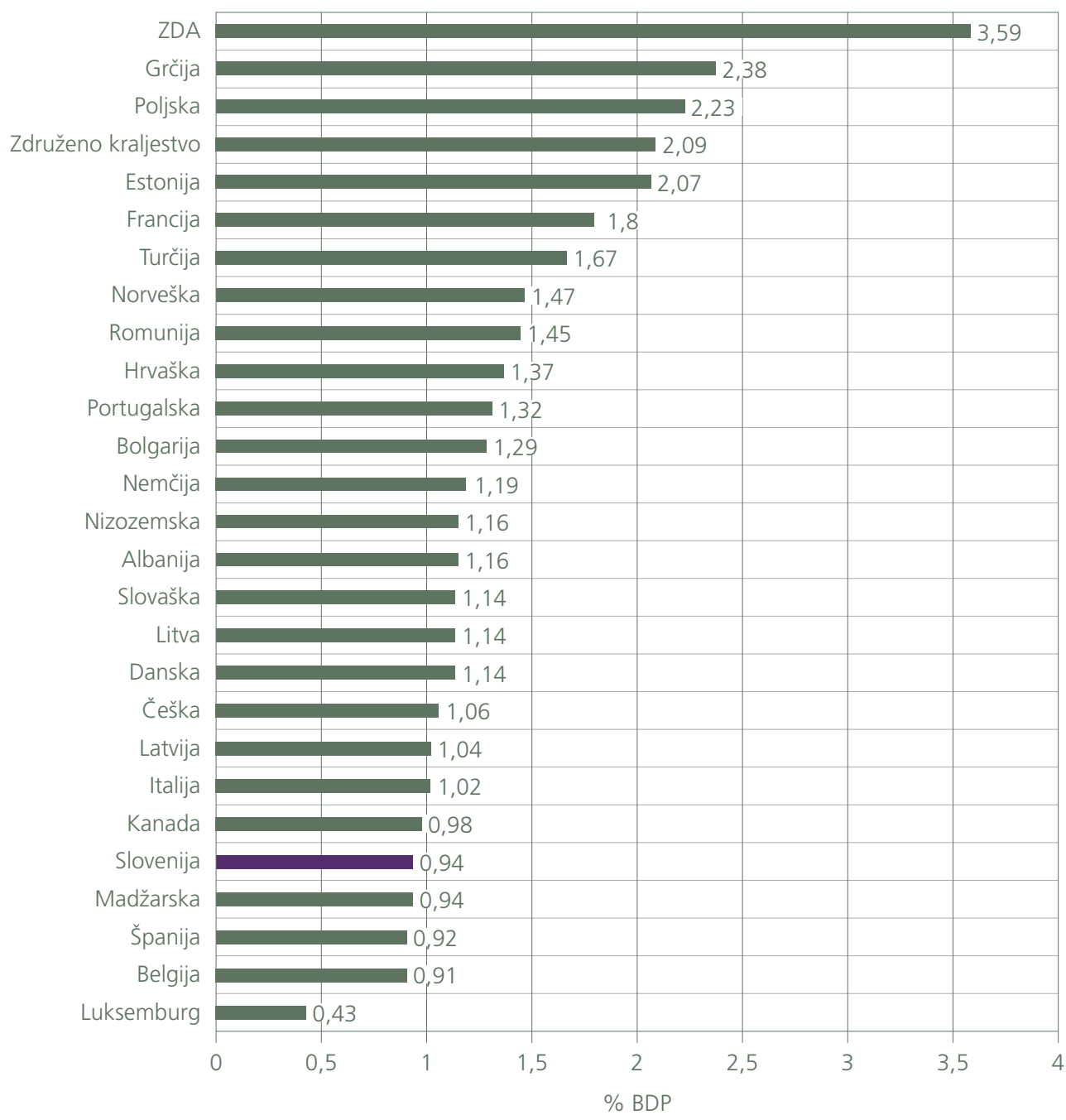

${ }^{8}$ Podatek o obrambnih izdatkih za Bolgarijo ne vključuje vojaških pokojnin. Opomba velja tudi za vse nadaljnje preračune, ki vključujejo Bolgarijo. 
Če je bila Slovenija z obrambnimi izdatki v višini 1,59 odstotka BDP leta 2009 blizu povprečja držav članic Nata (to je bilo 1,68 odstotka BDP) oziroma celo nad vrednostjo mediane (1,52 odstotka BDP), se je leta 2015 znašla na repu članic zavezništva. Še bolj kot višina obrambnih izdatkov je bila zaskrbljujoča struktura teh izdatkov. Izračunam lahko, da so države članice Nata leta 2015 za opremo namenile povprečno 15,59 odstotka obrambnih izdatkov, za stroške osebja 56,85 odstotka, za infrastrukturo 2,75 odstotka in za druge izdatke 24,81 odstotka obrambnih izdatkov. V povprečju ne gre za znatnejši odmik od leta 2009 , ko je bilo to razmerje $15,67: 57,01: 3,28: 24,03$. ${ }^{9}$

Graf 4:

Struktura obrambnih

izdatkov držav članic Nata

leta 2015

Vir:

Lastna

ponazoritev po podatkih Nata (2016, str. 8 in 9).

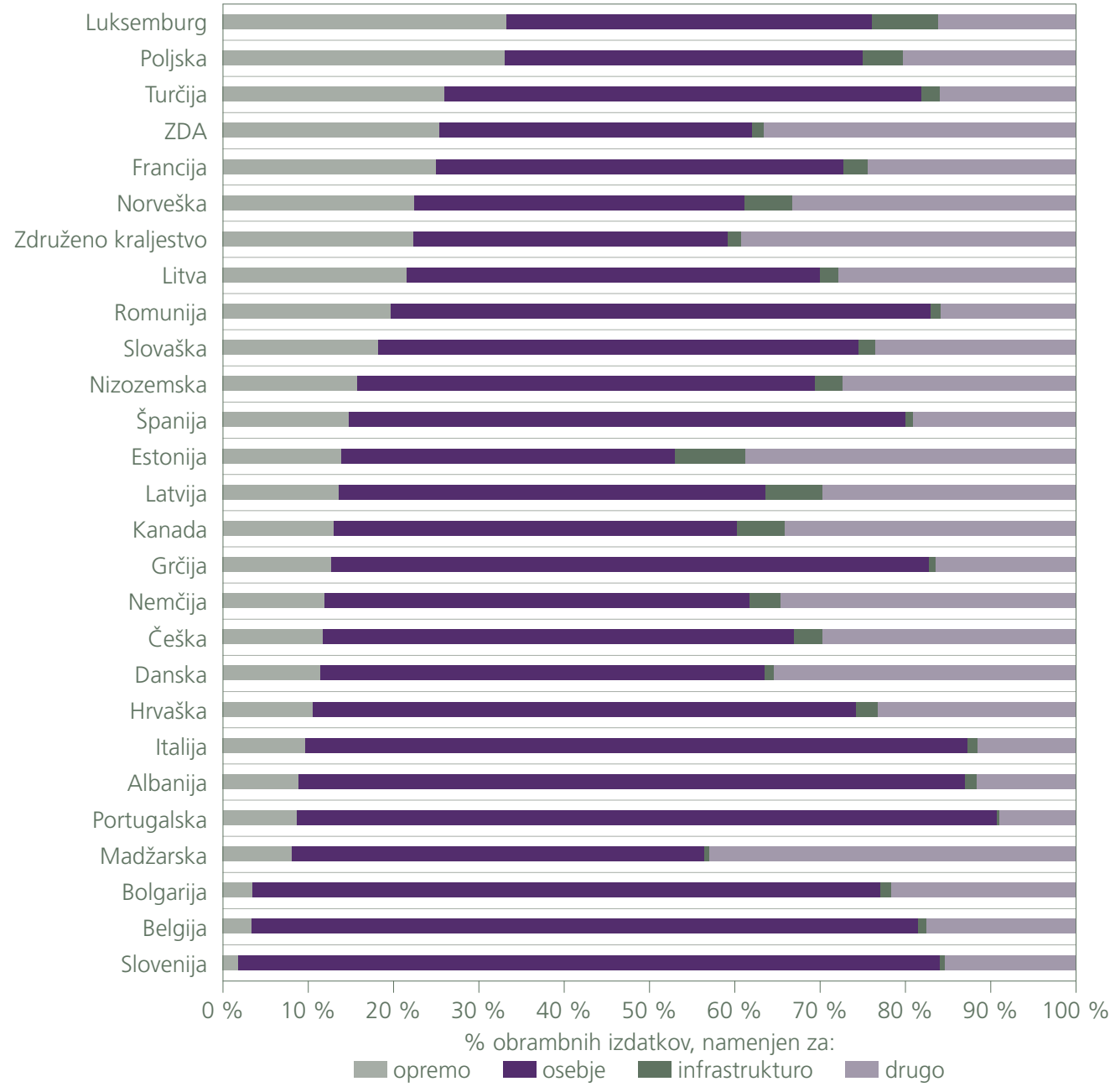

Natančnejša analiza pokaže, da se struktura izdatkov v letih 2009-2015 v povprečju ni bistveno spremenila (v letih 2011-2014 je v Natu sicer opazen manjši padec izdatkov za opremo za okoli dve odstotni točki in približno enak porast izdatkov za osebje), so se pa povečale relativne razlike med državami (koeficient variacije je npr. pri kategoriji vlaganj v opremo narastel z 0,39 na 0,54). Problematiko je med drugimi preučeval Becker (2016) in sklenil, da ob naraščajoči brezposelnosti države višajo delež izdatkov za osebje, saj imajo (v primerjavi z vlaganji v opremo) neposreden vpliv na stopnjo zaposlenosti. 
Slovenija, ki je imela z razmerjem 8,5:67,07:3,18:21,25 že leta 2009 precej neugodno razmerje, je leta 2015 za opremo namenila le 1,86 odstotka, za osebje kar 82,22 odstotka, za infrastrukturo 0,61 odstotka in za druge izdatke 15,31 odstotka obrambnih izdatkov. Tako je bila Slovenija v celotnem Natu na zadnjem mestu po vlaganjih v opremo, predzadnja po vlaganjih v infrastrukturo, imela je četrti najnižji odstotek sredstev za druge izdatke (torej za operativno delovanje in vzdrževanje), na drugi strani pa je bila vodilna po deležu izdatkov za osebje (graf 4)! ${ }^{10}$

Uravnoteženost strukture slovenskih obrambnih izdatkov pred krizo in med njo prikazuje graf 5. Če je bila Slovenija leta 2004 ob vstopu v Nato z 18,5 odstotka, namenjenih za opremo, po tovrstnih vlaganjih na devetem mestu med takratno šestindvajseterico oziroma nad povprečjem držav članic Nata, se je ta delež takoj v naslednjih letih znižal in se gibal okoli 10 odstotkov (leta 2005 je znašal 9,5 odstotka, 2006 12,2 odstotka in 2007 10,8 odstotka obrambnih izdatkov), kar je Slovenijo uvrščalo pod povprečje držav zaveznic. Leta 2008 je Slovenija s 7,4 odstotka obrambnih izdatkov, namenjenih opremi, prvič zasedla zadnje mesto med državami članicami, leta 2009 pa se je z 8,5 odstotka uvrstila kot tretja najnižje rangirana. Sledilo je leto prejema klirinškega dolga (2010, z 18 odstotki tik pod vrednostjo zgornjega kvartila), nato pa petletje 2011-5, ko je imela med vsemi državami članicami Slovenija vsako leto najnižji del obrambnih izdatkov, namenjen opremi (tj. 5,7, 1,2, 1,27, 0,66 in 1,86 odstotka) in hkrati, od leta 2013 naprej, najvišji delež obrambnih izdatkov, namenjen osebju (80,52, 82,31 in 82,22 odstotka).

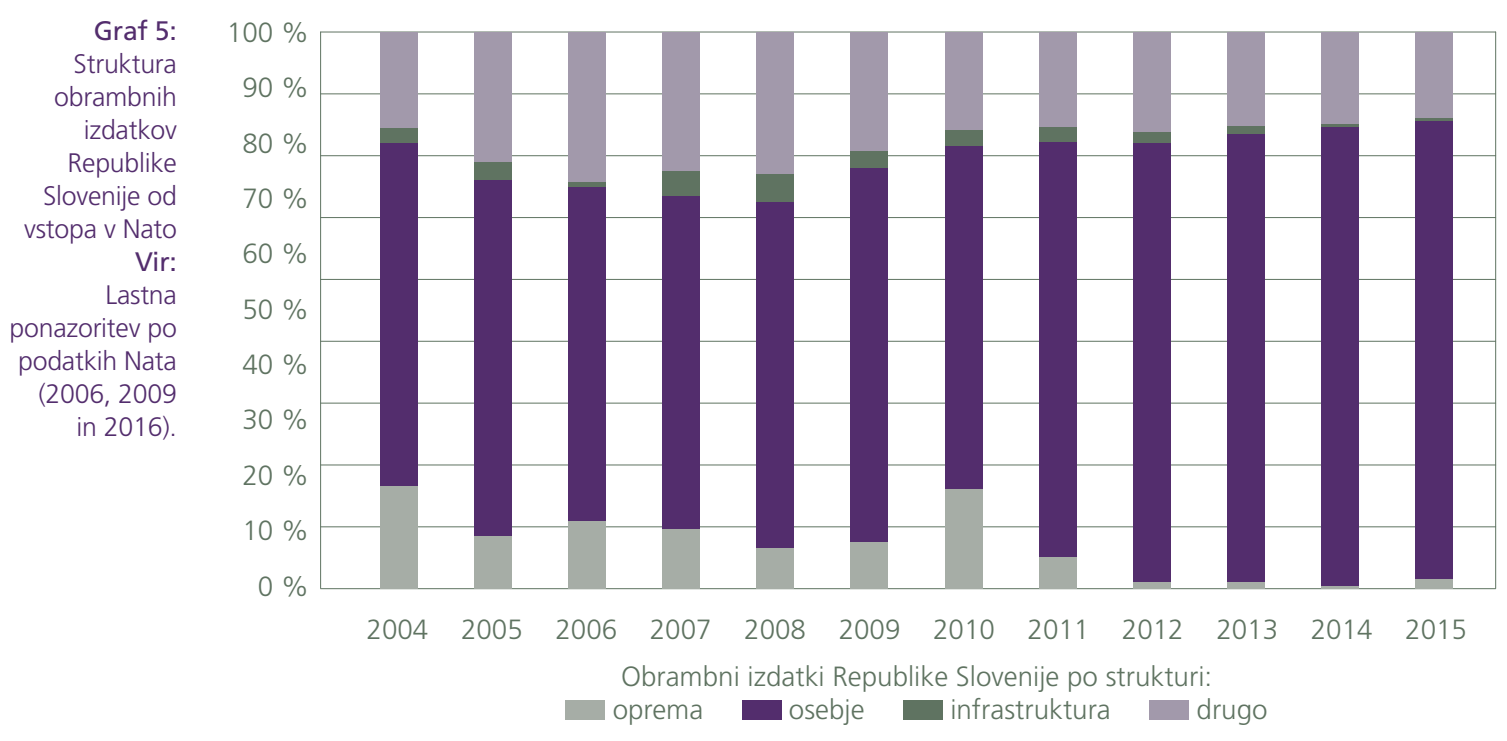

${ }^{10}$ Empirično lahko podkrepim tudi ugotovitve Younga (2016) o razlikah med postkomunističnimi in starejšimi članicami zavezništva. Izkaže se, da so imele postkomunistične države v obdobju 2009-2015 povprečno za 4,9 odstotne točke nižji delež izdatkov za opremo, za 5,4 odstotne točke višji delež izdatkov za osebje, medtem ko v preostalih dveh kategorijah ni bilo očitnejših razlik (-1 odstotna točka v kategoriji drugo in +0,6 odstotne točke pri infrastrukturi). 
Iz zgoraj prikazanega je razvidno, da ima slovenski obrambni sistem že dlje časa težave, ki izhajajo tako iz razmeroma nizkega obsega finančnih sredstev kot tudi iz neuravnotežene strukture obrambnih izdatkov, kar je nevzdržno za dolgoročno delovanje obrambnega sistema. Skladno z vladnimi napovedmi in Srednjeročnim obrambnim programom (2016, str. 42) naj bi se padanje slovenskih obrambnih izdatkov v deležu BDP sicer ustavilo leta 2017 pri 0,91 odstotka BDP, od leta 2018 naprej pa naj bi sledila letna rast v višini 0,04 odstotne točke na leto; tako naj bi obrambni izdatki leta 2020 znašali 1,03 odstotka BDP.

\section{OBRAMBNI IZDATKI IN OBSEG OBOROŽENIH SIL}

Obseg oboroženih sil je odvisen od številnih dejavnikov. V primeru Slovenije lahko opredelitev teh dejavnikov izluščim iz Resolucije o splošnem dolgoročnem programu razvoja in opremljanja Slovenske vojske do leta 2025 (str. 25), v kateri je navedeno, da bosta obseg in struktura kadrovskih virov Slovenske vojske temeljila na »njenih poslanstvih in nalogah, oceni varnostne ogroženosti Republike Slovenije, potrebnih zmogljivostih za uresničevanje nalog $\mathrm{v}$ nacionalnem in mednarodnem okviru, nacionalni ravni ambicij za delovanje Slovenske vojske ter razpoložljivosti finančnih virov«. Planirani skupni obseg Slovenske vojske bo do 10.000 pripadnikov, s ciljnim razmerjem med pripadniki stalne in prostovoljne pogodbene rezervne sestave $4: 1$ (Ibid.).

Po besedah Žabkarja (2003, str. 351) si vse države »želijo imeti moderno in učinkovito obrambo, nimajo pa enakih proračunskih sredstev, zato je razumljivo, da obrambnega sistema ne morejo oblikovati po svojih željah, ampak po obsegu proračunskih sredstev«. Žabkar (2004, str. 131) opozarja, da dolgoročno načrtovanje »nosi v sebi tveganja, da med razvojem pride do dodatnih velikih sprememb; zato je bilo načrtovanje razvoja oboroženih sil vedno povezano s kakovostjo predvidevanja [...]. Pri dolgoročnem načrtovanju oboroženih sil je koristno, če se izhaja iz treh inačic obrambnega proračuna; tako se za načrtovalno obdobje 10-15 let določijo trije najverjetnejši deleži nacionalnega dohodka - maksimalni, srednji in minimalni. Nato se za vsakega od teh deležev določi vsota, ki pride v poštev za razvoj oboroženih sil«. Iz navedenega lahko ugotovim, da pri idealnotipskem načrtovanju razvoja oboroženih sil kadrovski obseg sil predstavlja odvisno spremenljivko, obrambni izdatki pa eno izmed neodvisnih spremenljivk. ${ }^{11}$

Ob tem je treba dodati, da sta tako kadrovski kot strukturni obseg oboroženih sil tesno povezana s sistemom popolnjevanja. Kopač (2010, str. 65-70) podaja

\footnotetext{
II Temu pritrjuje tudi Doško (2013), ki je preučeval kadrovsko politiko čeških in nekdanjih češkoslovaških oboroženih sil. Doško je v svojem članku identificiral naslednje neodvisne spremenljivke, ki vplivajo na kadrovsko politiko: (1) subjektivno varnostno situacijo, (2) varnostna jamstva (zavezništva), (3) javno mnenje, (4) gospodarsko dinamiko, (5) finančne vire in (6) drugo (kot so potreba po dodatnem osebju za mednarodne operacije in misije). Doško sicer opozarja, da so finančni viri v nekaterih primerih lahko tudi odvisna spremenljivka. Glede na opredelitev $v$ Resoluciji o splošnem dolgoročnem programu razvoja in opremljanja Slovenske vojske do leta 2025 (str. 25) in iz analogije med češkim in slovenskim primerom sklepam, da v Sloveniji ni tako.
} 
teoretičen pregled nad različnimi tipskimi klasifikacijami popolnjevanja oboroženih sil, v nadaljnji analizi pa je uporabljena najpreprostejša delitev, tj. na poklicne oziroma prostovoljne oborožene sile (all volunteer force) in obvezniške oborožene sile (conscripted force). Ker so stroški na vojaškega obveznika praviloma bistveno nižji od stroškov na poklicnega vojaka (saj so osebni prejemki vojaških obveznikov praviloma pod tržno vrednostjo oziroma nižji od prejemkov poklicnih pripadnikov), sem članice Nata, ki se popolnjujejo z obvezniki, iz nadaljnje analize izključil. ${ }^{12}$

\section{BIVARIATNA ANALIZA}

Za preverjanje domneve o povezanosti dveh številskih spremenljivk - višine obrambnih izdatkov in kadrovskega obsega oboroženih sil - sem izvedel bivariatno analizo. Da bi lahko primerjal različno velike sisteme oziroma države, sem indikator kadrovskega obsega oboroženih sil izrazil s številom pripadnikov oboroženih sil na 1000 prebivalcev, višino obrambnih izdatkov pa v deležu BDP. Pri tem sem za obdobje 2009-2015 ugotovil zmerno pozitivno korelacijo (vrednost Pearsonovega koeficienta korelacije je po posameznih letih med 0,59 in 0,70) (Brvar 2007, 261). ${ }^{13}$

Kot je bilo izpostavljeno $\mathrm{v}$ tretjem poglavju, slovenski obrambni sistem bremeni še posebej visok delež izdatkov za osebje, zato sem želel preučiti še, ali je bil kadrovski obseg Slovenske vojske v obdobju 2009-2015 sorazmeren glede na izdatke za osebje. Ponovno sem izvedel bivariatno analizo, pri čemer sem tokrat ugotavljal povezanost višine obrambnih izdatkov za osebje s kadrovskim obsegom oboroženih sil. Da bi lahko primerjal različno velike sisteme oziroma države, sem indikator kadrovskega obsega oboroženih sil ponovno izrazil s številom pripadnikov oboroženih sil na 1000 prebivalcev, višino obrambnih izdatkov za osebje pa v deležu BDP (graf6). Slovenija je na grafu označena z vijoličnimi, druge države članice zveze Nato pa z zelenimi točkami.

Ne preseneča ugotovitev, da so v primerjavi s celotnimi obrambnimi izdatki obrambni izdatki za osebje precej tesneje pozitivno povezani s kadrovskim obsegom oboroženih sil (vrednost Pearsonovega koeficienta korelacije je po posameznih letih med 0,80 in 0,87 , kar kaže na visoko pozitivno korelacijo) (Brvar 2007, 261). ${ }^{14}$ Povezanost spremenljivk bi sicer najbolj razumno opisala nelinearna funkcija - s krivuljo je nakazana na spodnjem desnem grafu. Kot ugotavlja Fisher (v Kopač, 2010, str. 83), je namreč plačna elastičnost ponudbe poklicne vojaške delovne sile razmeroma velika, če

\footnotetext{
12 Te države so: Danska, Estonija, Grčija, Norveška in Turčija v celotnem obravnavanem obdobju, Albanija do leta 2010, Nemčija do leta 2011 in Litva leta 2015. Prav tako je iz analize izključena Islandija, ki nima konvencionalnih oboroženih sil.

${ }_{13}$ S primerjavo postkomunističnih držav s starejšimi državami članicami ugotovim, da so prve za obrambo namenjale povprečno 1,26 odstotka BDP, slednje pa 1,57 odstotka BDP, pri čemer so imele oboje povprečno skoraj enak obseg oboroženih sil (2,80 pripadnika oziroma 2,84 pripadnika na 1000 prebivalcev). Razvidna je diskrepanca, na katero opozarja Young (2016, str. 20), ki je postkomunističnim državam omejevala vlaganja v opremo.

${ }_{14}$ Vrednost koeficienta determinacije je po posameznih letih med 0,64 in 0,76 (koeficient determinacije kaže na to, kolikšen je delež pojasnjene variance v odvisni spremenljivki) (Statistic and Probability Dictionary, 2017). Del nepojasnjene variance razlaga dejstvo, da države manjši del kadrovskih izdatkov namenjajo tudi za financiranje rezervne sestave, ki jo ta analiza ne zajema.
} 
Graf 6: Razmerje med obrambnimi izdatki za osebje in kadrovskim obsegom oboroženih sil v državah članicah

Nata s poklicnim popolnjevanjem (2009-2015) Vir:

Lastna ponazoritev po podatkih Nata (2016), Eurostata (2017), Statistics Canade (2017) in United States Census Bureauja (2017).
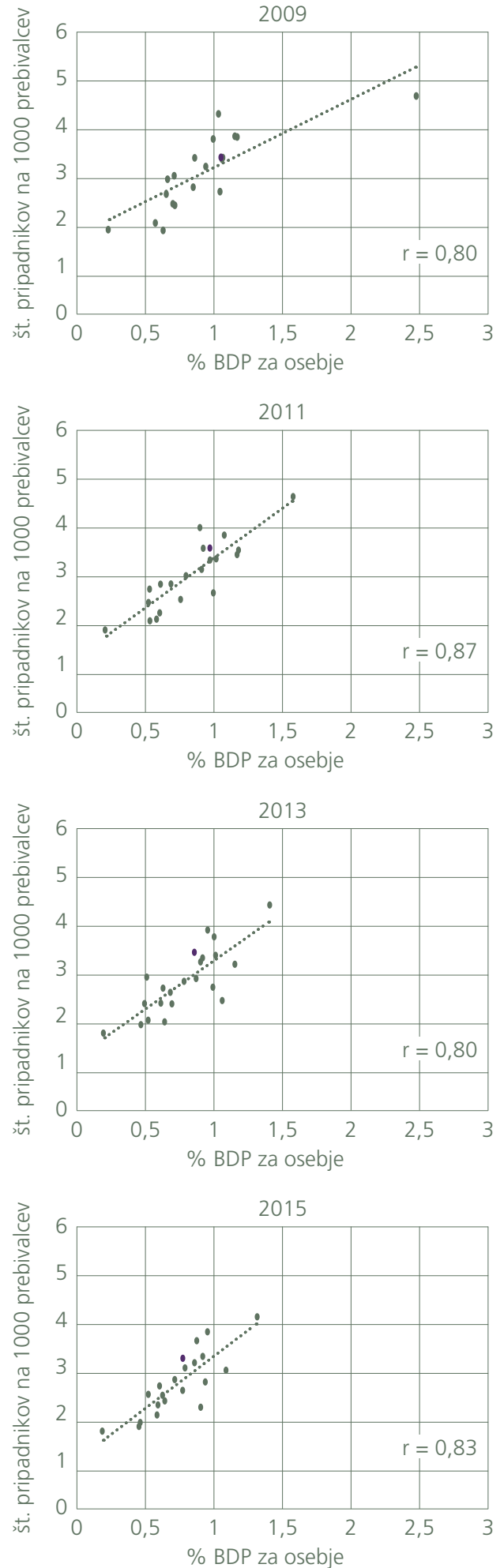
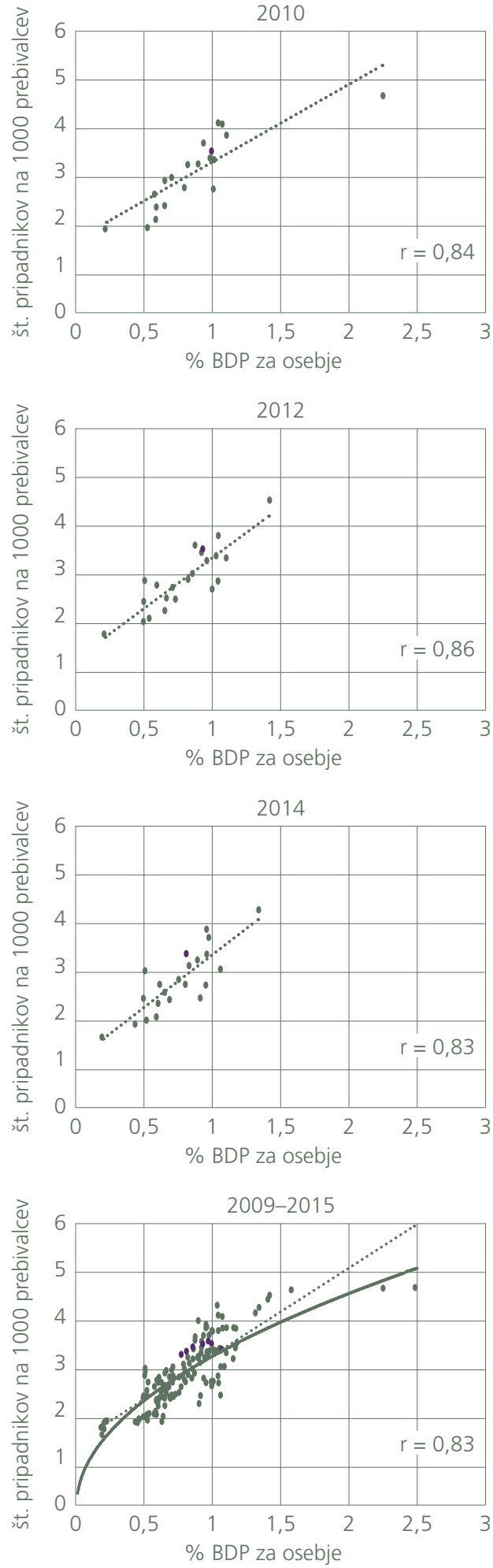
vojaško službo nastopi razmeroma majhen del primerne populacije in obratno. ${ }^{15}$ Ker pa nelinearna funkcija na opazovanem intervalu ne odstopa bistveno od linearne, analiza temelji na linearni poenostavitvi. Ob tem - na podlagi teoretskih izhodišč - sklepam na vzročno povezanost obravnavanih spremenljivk (višina obrambnih izdatkov za osebje vpliva na število pripadnikov oboroženih sil).

Glede na rezultate opravljene analize lahko sklenem: (1) da so države članice Nata v obdobju 2009-2015 ob povečanju obrambnih izdatkov za osebje za 0,1 odstotne točke BDP lahko zaposlile približno 0,2 dodatnega vojaka na 1000 prebivalcev in obratno, pri čemer (2) model bolje pojasnjuje razmerje v starejših državah članicah kot $\mathrm{v}$ postkomunističnih ${ }^{16}$ in (3) da je imela Slovenija v obdobju 2009-2015 kadrovski obseg oboroženih sil sorazmeren z obrambnimi izdatki za osebje, ne pa tudi s celotnimi obrambnimi izdatki.

Na podlagi izsledkov o večletnem gibanju razmerja med obrambnimi izdatki za osebje in kadrovskim obsegom oboroženih sil v Sloveniji in drugih državah članicah Nata s poklicnim popolnjevanjem lahko na podlagi vrednosti neodvisne spremenljivke predvidevam vrednost odvisne spremenljivke tudi za v prihodnje. S tem v naslednjem poglavju iz področja korelacijske analize stopam na raven (enostavne) regresije.

Ker v nadaljnji analizi posebno pozornost namenjam Sloveniji, v tabeli 1 predstavljam ključne kazalnike kadrovskega razvoja Slovenske vojske. ${ }^{17}$

\begin{tabular}{|c|c|c|c|c|c|c|c|c|c|}
\hline \multirow{6}{*}{$\begin{array}{r}\text { Tabela 1: } \\
\text { Kazalniki } \\
\text { kadrovskega } \\
\text { razvoja Slovenske } \\
\text { vojske v letih } \\
2009-2015 \text { in } \\
\text { projekcija načrto- } \\
\text { vanega stanja za } \\
\text { leto } 2020\end{array}$} & & '09 & $' 10$ & $' 11$ & $' 12$ & 13 & $' 14$ & $' 15$ & '20 \\
\hline & 1) število prebivalcev (v tisočih) & 2032 & 2047 & 2050 & 2055 & 2059 & 2061 & 2063 & 2071 \\
\hline & 2) število pripadnikov ${ }^{17}$ & 6755 & 7053 & 7171 & 7061 & 6947 & 6764 & 6628 & 7150 \\
\hline & 3) celotni o. izdatki (\% BDP) & 1,59 & 1,61 & 1,30 & 1,18 & 1,06 & 0,98 & 0,94 & 1,03 \\
\hline & 4) o. izdatki za osebje (\% BDP) & 1,07 & 0,99 & 0,97 & 0,93 & 0,86 & 0,81 & 0,77 & 0,69 \\
\hline & 5) št. pripadnikov na 1000 preb. & 3,32 & 3,45 & 3,50 & 3,44 & 3,37 & 3,28 & 3,21 & 3,45 \\
\hline
\end{tabular}

Vir: Lasten izračun po podatkih Umarja (2013), Nata (2016), Srednjeročnega obrambnega programa (2016, str. 36 in 41-42) in Eurostata (2017).

${ }^{15}$ Po mnenju Altmana in Fechterja (v Kopač 2010, str. 83) naj bi bil razlog za to v »dejstvu, da je zaposlitev $v$ oboroženih silah najprej privlačna za tiste, ki prejemajo nižja alternativna plačila za delo in imajo visoke preference do vojaškega življenja. Zato je po njunem logično pričakovati, da se morajo pri potrebnem povečanju obsega ponudbe poklicne vojaške delovne sile vojaška plačila povečevati«.

${ }_{16}$ Če za obdobje 2009-2015 izračunam pojasnjeno in celotno varianco za posamezni skupini držav, ugotovim, da je pojasnljivost modela za starejše članice zavezništva višja (pojasnjena varianca obsega 81 odstotkov celotne) kot pa za postkomunistične države članice (pojasnjena varianca $v$ višini 52 odstotkov celotne).

${ }_{17}$ Podatki o številu pripadnikov so vzeti iz evidenc zveze Nato in zaradi razlik v definicijah odstopajo od prikazanih v nacionalnih poročilih. Analogno je opravljen preračun predvidenega stanja leta 2020, pri čemer je 7600 pripadnikov po nacionalnih dokumentih ocenjeno na 7150 pripadnikov po definiciji Nata. 


\section{APLIKACIJA IZSLEDKOV ZA LETO 2020}

V Srednjeročnem obrambnem programu Republike Slovenije 2016-2020 (str. 5 in 36) je predvideno, da bo ob koncu srednjeročnega obdobja »obseg Slovenske vojske znašal do 9100 pripadnikov, od tega 7600 stalne in 1500 rezervne sestave $\ll$, pri čemer je »zagotavljanje končnega obsega Slovenske vojske v okviru 7600 pripadnikov stalne sestave in 1500 pripadnikov pogodbene rezervne sestave« določeno kot »temeljni cilj na kadrovskem področju«. Srednjeročni obrambni program predvideva, da bodo leta 2020 obrambni izdatki povečani na 1,03 odstotka BDP, razrez pa bo predvidoma tak: 67 odstotkov sredstev bo namenjenih za osebje, 18 odstotkov za operacije in vzdrževanje (oziroma za »druge izdatke«, če jih prevedem v Natovo kategorijo) in 15 odstotkov za nabave in gradnje (oziroma za Natovi kategoriji »oprema« in »infrastruktura«). Ugotovim lahko, da bi se ob uresničitvi programa Slovenska vojska leta 2020 sicer približala, a še vedno ostala pod Natovim povprečnim razmerjem iz leta 2015 (ki je bilo $57: 25: 18$ ). Še več, preračunam lahko, da razrez obrambnih izdatkov predvideva, da se bodo slovenski obrambni izdatki za osebje predvidoma z 0,77 odstotka BDP leta 2015 znižali na 0,69 odstotka BDP leta 2020, pri čemer pa se de facto načrtuje ponovno povečanje kadrovskega obsega Slovenske vojske na okoli 3,45 pripadnika na 1000 prebivalcev (tabela 1), kar bi vodilo v bistveno poslabšanje razmerja med obrambnimi izdatki za osebje in kadrovskim obsegom Slovenske vojske. Če k temu dodam, da Ministrstvo za obrambo Republike Slovenije že od leta 2013 ponovno zaznava negativen trend zaposlovanja v Slovenski vojski, saj »zahteve in zahtevnost vojaškega poklica ne pritegneta morebitnih kandidatov k zaposlitvi v Slovenski vojski«, da že od leta 2014 naprej opozarja, da navedena vzroka v povezavi z »višino plače vojakov odvrača potencialne kandidate od zaposlitve v Slovenski vojski«, lahko sklenem, da je doseganje kadrovsko-finančnih ciljev iz Srednjeročnega obrambnega programa nerealno (Letno poročilo Ministrstva za obrambo za leto 2013, str. 85; Letno poročilo Ministrstva za obrambo za leto 2013, str. 84). Na podlagi tega lahko pričakujem, da brez povišanja plačil pripadnikov kadrovskih trendov ne bo mogoče obrniti, ${ }^{18}$ pri čemer pa je povečanje plačil neizogibno povezano bodisi z dodatnimi finančnimi prilivi bodisi z zmanjševanjem kadrovskega obsega Slovenske vojske.

$\mathrm{Ob}$ upoštevanju visoke pozitivne korelacije med obrambnimi izdatki za osebje in kadrovskim obsegom oboroženih sil lahko predvidevam, da skladno s Srednjeročnim obrambnim programom načrtovani obrambni izdatki Republike Slovenije za leto 2020 omogočajo ohranitev strukture Slovenske vojske v obsegu približno treh pripadnikov na 1000 prebivalcev (skupno 6200 pripadnikov po definiciji Nata oziroma približno 6600 po nacionalni evidenci). Ocena je optimistična, saj bo, kot

\footnotetext{
18 V povezavi s tem je Vlada Republike Slovenije avgusta 2017 sprejela Uredbo o spremembah Uredbe o uvrstitvi formacijskih dolžnosti in nazivov $v$ Slovenski vojski v plačne razrede, skatero so se povišale plače v Slovenski vojski na večini vojaških ter nekaterih podčastniških in častniških formacijskih dolžnostih do vključno čina stotnika, in sicer za do dva plačna razreda. Nadaljnja povišanja so bila 29. 9. 2017 še v medresorskem usklajevanju. Poleg tega sta v času zaključevanja prispevka v državnozborskem postopku tudi Zakon o obrambi in Zakon o službi v Slovenski vojski, v katerih so predvideni (1) dodatek za prepoved stavke, (2) spregled izobrazbe za vojake s srednjo poklicno izobrazbo in (3) povišano izplačevanje posebnih nagrad.
} 
je bilo prikazano zgoraj, zaradi dinamike na trgu dela najverjetneje treba poseči po znatnejšem povečanju plačil v Slovenski vojski. V tem primeru bi načrtovani obrambni izdatki za osebje zahtevali dodatno zmanjšanje števila pripadnikov. Na podlagi regresijskega modela ocenjujem, da bi sredstva omogočala ohranitev okoli 2,75 pripadnika na 1000 prebivalcev (skupno 5700 pripadnikov po evidenci Nata oziroma 6000 po nacionalni definiciji). Tako bi bilo omogočeno ustrezno financiranje kadrov, ohranitev predvidenega financiranja operacij in vzdrževanja (18 odstotkov) ter nabav in gradenj (15 odstotkov obrambnih izdatkov), kar pa bi bilo kljub temu še vedno pod dolgoletnim povprečjem zveze Nato.

Kot izpostavlja Potočnik (2016, str. 18), vsaka država potrebuje ljudi za zagotavljanje varnosti in obrambe, teh pa ni mogoče nadomestiti s tehnologijo ali drugimi sredstvi. Ker si tudi države z manjšim številom prebivalcev prizadevajo za pokritje vseh varnostnih funkcij, lahko to tem državam povzroči težave. Če predpostavljam, da je popolnitev s 7600 poklicnimi pripadniki za Slovensko vojsko smiselna, bi morala Slovenija leta 2020 za obrambne izdatke predvidoma nameniti okoli 1,6 odstotka BDP, da bi dosegla v Srednjeročnem obrambnem programu zastavljene strukturno-finančne cilje oziroma 1,9 odstotka BDP, če bi želela doseči povprečno strukturo obrambnih izdatkov v zavezništvu. Če pa bi želela Slovenija vlagati priporočenih 20 odstotkov sredstev v izdatke za opremo in hkrati doseči načrtovano kadrovsko popolnitev, bi morala za celotne obrambne izdatke nameniti več kot dva odstotka BDP. Nekatere alternativne različice razvoja Slovenske vojske za leto 2020 predstavljam v tabeli 2.

\begin{tabular}{|c|c|c|c|c|c|c|c|}
\hline \multirow{5}{*}{$\begin{array}{r}\text { Tabela 2: } \\
\text { Izbrane alterna- } \\
\text { tivne različice } \\
\text { višine financiranja } \\
\text { in kadrovskega } \\
\text { obsega Slovenske } \\
\text { vojske (projekcija } \\
\text { za leto 2020) }\end{array}$} & & \multirow{2}{*}{$\begin{array}{l}\% \text { BDP za } \\
\text { obrambne } \\
\text { izdatke }\end{array}$} & \multirow{2}{*}{$\begin{array}{l}\text { Število poklicnih } \\
\text { pripadnikov SV (po } \\
\text { nacionalni definiciji) }\end{array}$} & \multicolumn{4}{|c|}{ Obrambni izdatki za: } \\
\hline & & & & Opremo & Osebje & Infrastrukturo & Drugo \\
\hline & A & 1,03 & 6000 & $13 \%$ & $67 \%$ & $2 \%$ & $18 \%$ \\
\hline & B & 1,2 & 6500 & $13 \%$ & $67 \%$ & $2 \%$ & $18 \%$ \\
\hline & C & 1,3 & 6800 & $13 \%$ & $67 \%$ & $2 \%$ & $18 \%$ \\
\hline $\begin{array}{l}\text { VIr: } \\
\text { lasten. }\end{array}$ & $\check{C}$ & 1,6 & 7600 & $13 \%$ & $67 \%$ & $2 \%$ & $18 \%$ \\
\hline & D & 1,8 & 7300 & $16 \%$ & $57 \%$ & $2 \%$ & $25 \%$ \\
\hline & $E$ & 2,0 & 7300 & $20 \%$ & $50 \%$ & $3 \%$ & $27 \%$ \\
\hline
\end{tabular}

Potočnik (2015), ki se je ukvarjal s problematiko obsega in značaja Slovenske vojske, je zapisal, da so bile v preteklosti že predstavljene bolj ali manj formalne ideje o zmanjševanju obsega in strukture Slovenske vojske, pri čemer naj bi se najpogosteje omenjalo zmanjšanje na okoli 5000 poklicnih pripadnikov. Ob tem je izpostavil(ibid.), da - po javno dostopnih podatkih - Slovenija zgolj za zagotavljanje zmogljivosti, dogovorjenih v okviru zveze Nato, potrebuje okoli 6500 poklicnih pripadnikov. Po besedah avtorja naj bi bil to minimalen obseg, pod katerega se Slovenska vojska nikakor ne bi smela spustiti, pri čemer pa bi imelo tovrstno zmanjšanje kadrovske 
sestave že negativne posledice na zagotavljanje nacionalne varnosti. Potočnik je zaključil (2015, str. 44-45), da je »vztrajanje pri številkah, ki jih finance ne dopuščajo, lahko le kontraproduktivno«, a hkrati pozval k izjemni previdnosti pri argumentaciji morebitnega zmanjševanja kadrovskega obsega Slovenske vojske.

Sklep V prispevku sem empirično preveril domnevo o povezanosti višine obrambnih izdatkov z obsegom oboroženih sil. Bivariatna analiza je razkrila, da obstaja zmerna pozitivna korelacija med višino obrambnih izdatkov in kadrovskim obsegom oboroženih sil ter tesnejša, visoka pozitivna korelacija, če v analizo namesto celotnih vključim le obrambne izdatke za osebje. ${ }^{19}$ Preučitev obrambnih izdatkov Republike Slovenije in primerjava z državami zaveznicami je pokazala, da je Slovenijo že pred nastopom javnofinančne krize bremenila razmeroma neugodna struktura obrambnih izdatkov, ki pa se je po proračunskih rezih še poslabševala - predvsem zato, ker Slovenija ob drastičnem krčenju obrambnih izdatkov ni bistveno posegala v kadrovski obseg oboroženih sil.

Navedeno podpira ugotovitve Younga (2016, str. 32), ki poudarja, da Slovenijo bremeni nekoherentnost obrambne politike, vključno z nejasno postavljenimi finančnimi prednostnimi nalogami, in izpostavlja nujnost sprememb v obrambnem načrtovanju, ki naj binamestona težnjahtemeljilona realno ocenjenihfinančnih prioritetah. Paradoksalno je, da srednjeročni razvoj Slovenske vojske temelji na razvojno-usmerjevalnem dokumentu, v katerem je na eni strani predviden nadaljnji padec obrambnih izdatkov za osebje v deležu BDP, na drugi strani pa de facto ponovna krepitev kadrovskega obsega Slovenske vojske. V želenem končnem stanju, razvidnem iz Srednjeročnega obrambnega programa, je implicirana predimenzionirana kadrovska sestava glede na načrtovane finančne vire. Na podlagi regresijske analize predvidevam, da bi Slovenska vojska za leto 2020 zastavljene kadrovske (7600 poklicnih pripadnikov) in strukturnofinančne cilje (razmerje $67: 18: 15$ ) lahko dosegla le ob povišanju celotnih obrambnih izdatkov na okoli 1,6 odstotka BDP. Že ohranitev trenutnega obsega Slovenske vojske (6826 poklicnih pripadnikov) ${ }^{20}$ bi ob upoštevanju ciljnega strukturno-finančnega razmerja zahtevala dvig obrambnih izdatkov na okoli 1,3 odstotka BDP. Ker tako drastična rast obrambnih izdatkov ni niti načrtovana niti pričakovana, obstaja realna bojazen, da bodo odločevalci ponovno primorani v izbiro med (1) zmanjševanjem števila poklicnih pripadnikov Slovenske vojske (s čimer bi lahko dosegli predvideno strukturno razmerje obrambnih izdatkov), med (2) prerazporejanjem investicijskih in operativnih postavk v izdatke za osebje oziroma v (3) izvedbo kompromisa med obema možnostma. Ob tem velja opozoriti, da bi vsakršno poseganje $\mathrm{v}$ že tako ne ravno ambiciozno zastavljene investicijske in operativne postavke neizogibno vodilo $\mathrm{v}$ nadaljnjo degeneracijo bojnega potenciala Slovenske vojske, zmanjševanje kadrovskega obsega pa bi - kot ugotavlja Potočnik (2015) - Slovensko vojsko vodilo v nezmožnost opravljanja zakonsko predvidenih nalog.

\footnotetext{
19 Vluči znanstvenega preučevanja problematike bi bilo pristop v prihodnje mogoče nadgraditi z multiplo regresijsko analizo, tj. z vključitvijo širšega nabora neodvisnih spremenljivk.

${ }^{20}$ Podatek za november 2017 (Slovenska vojska, 2017).
} 
Glede na navedeno lahko sklenem, da doseganje srednjeročnih kadrovskih in strukturno-finančnih ciljev ob predvideni rasti obrambnih izdatkov ni realno uresničljivo. Prognoza za leto 2020 vzbuja zaskrbljenost in kaže na nujnost sprememb v obrambnem načrtovanju. Gordijski vozel, ki se zapleta že vse od slovenskega vstopa v zavezništvo, bi bilo mogoče presekati le z dosego soglasja na strokovni in politični ravni o dolgoročno vzdržni višini in strukturi financiranja na eni ter ustrezno prilagojenem obsegu Slovenske vojske na drugi strani.

\section{Literatura}

1. Becker, J., 2016. The Effect of Unemployment on Transatlantic Burden-Sharing. https:// papers.ssrn.com/sol3/papers.cfm?abstract_id=2660703, 14.8. 2017.

2. Brvar, B., 2007. Statistika. Ljubljana: Fakulteta za varnostne vede.

3. Doško, P., 2013. Comparison of Military Manpower Policy in the Czech Republic and the Former Czechoslovakia. http://www.sekuritaci.cz/comparison-of-military-manpower-policyin-the-czech-republic-and-the-former-czechoslovakia/, 30. 3. 2017.

4. Državni zbor Republike Slovenije. 2010a. Resolucija o strategiji nacionalne varnosti Republike Slovenije (ReSNV-1). http://www.pisrs.si/Pis.web/pregledPredpisa? id=RESO61, 18. 11. 2016.

5. Državni zbor Republike Slovenije. 2010b. Resolucija o splošnem dolgoročnem programu razvoja in opremljanja Slovenske vojske do leta 2025. http://www.mo.gov.si/fileadmin/ mo.gov.si/pageuploads/pdf/ministrstvo/ReDPROSV25_slo_en.pdf, 18. 11. 2016.

6. Eržen, B., 2015. Slovenska vojska namenila 50 tisočakov za oglaševanje 333 zaposlitev. http://www.zurnal24.si/slovenska-vojska-namenila-50-tisocakov-za-oglasevanje-332zaposlitev-clanek-258518, 18. 11. 2016.

7. Eurostat. 2017. Population data. http://ec.europa.eu/eurostat/web/population-demographymigration-projections/population-data, 7. 4. 2017.

8. Grizold, A., 1999. Obrambni sistem Republike Slovenije. Ljubljana: Ministrstvo za notranje zadeve, Visoka policijska-varnostna šola.

9. Karba, D., 2016. Andreja Katič: V Sloveniji smo navajeni živeti v balončku varnosti. https:// www.dnevnik.si/1042750355, 5. 4. 2017.

10. Kopač, E., 2010. Trg vojaške delovne sile - študija primera Slovenije. Ljubljana: FDV. http://dk.fdv.uni-lj.si/doktorska_dela/pdfs/dr_kopac-erik.PDF, 13. 12. 2016.

11. Kotnik, I., 2014. Nikoli ne bomo svetovni prvaki v težki kategoriji, lahko pa smo v peresni. http://www.delo.si/zgodbe/sobotnapriloga/nikoli-ne-bomo-svetovni-prvaki-v-tezki-kategorijilahko-pa-smo-v-peresni.html, 7. 4. 2017.

12. Kotnik, I., 2016. Nacionalna varnost: Bodeča žica-preveč ali v resnici premalo? https:// www.dnevnik.si/1042729620/slovenija/nacionalna-varnost-bodeca-zica-prevec-ali-v-resnicipremalo, 7. 4. 2017.

13. L. L., A. Č. 2017. Pahor: Slovenska vojska ostaja na najnižji sposobnosti delovanja. http://www.rtvslo.si/slovenija/pahor-slovenska-vojska-ostaja-na-najnizji-sposobnostidelovanja/416954, 5. 4. 2017.

14. Masten, A., 2016. Težke besede o Slovenski vojski: na najnižji stopnji pripravljenosti, neprimerna za oborožen boj. http://www.rtvslo.si/slovenija/tezke-besede-o-slovenski-vojskina-najnizji-stopnji-pripravljenosti-neprimerna-za-oborozen-boj/389402, 18. 11. 2016.

15. Ministrstvo za obrambo Republike Slovenije. 2010-2016. Letna poročila Ministrstva za obrambo. Ljubljana: MORS. http://www.mo.gov.si/si/zakonodaja_in_dokumenti, 12. 12. 2016.

16. Nato. 2006. Nato-Russia compendium of financial and economic data relating to defence. http://www.nato.int/nato_static_fl2014/assets/pdf/pdf_2006_12/20090901_p06-159.pdf, 22. 11. 2016. 
17. Nato. 2010. Financial and economic data relating to NATO defence. http://www.nato.int/ nato_static fl2014/assets/pdf/pdf_2010_06/20100610_PR_CP_2010_078.pdf, 22. 11. 2016.

18. Nato. 2016. Defence Expenditures of NATO Countries (2009-2016). http://www.nato.int/nato static_fl2014/assets/pdf/pdf_2016_07/20160704_160704-pr2016-116.pdf, 22. 11. 2016.

19. Nato. 2017. Funding NATO. http://www.nato.int/cps/en/natohq/topics_67655.htm, 20. 4. 2017.

20. Potočnik, G., 2016. Sodelovanje vojske in policije v sodobni državi: primer Slovenije. Ljubljana: Fakulteta za družbene vede. http://dk.fdv.uni-lj.si/doktorska_dela/pdfs/dr potocnik-gregor.pdf, 10. 4. 2016.

21. Potočnik, V., 2015. Obseg in karakter Slovenske vojske. V Sodobni vojaški izzivi, 4 (17), str. 27-46. http://www.slovenskavojska.si/fileadmin/slovenska_vojska/ pdf/vojaski_ izzivi/2015/svi_17_4.pdf, 5. 4. 2017.

22. Slovenska vojska. 2017. O Slovenski vojski. http://www.slovenskavojska.si/o-slovenskivojski/, 15. 11. 2017.

23. Stańczyk, K., 2014. Current trends in world defence expenditure. V Revista Academiei Fortelor Terestre Nr. 3 (75), str. 313-318. http: http://www.armyacademy. ro/revistel rev3_2014/STANCYZC.pdf, 5. 12. 2016.

24. Statistic and Probability Dictionaty. 2017. Coefficient of determination. http://stattrek.com/ statistics/dictionary.aspx?definition=coefficient_of_determination, 5. 4. 2017.

25. Statistics Canada. 2017. http://www.statcan.gc.ca/eng/start, 7. 4. 2017.

26. Škrjanc, R., 2016. Vojaki opozarjajo na slab socialni položaj, predvsem na težave z upokojevanjem. http://www.rtvslo.si/slovenija/vojaki-opozarjajo-na-slab-socialni-polozajpredvsem-na-tezave-z-upokojevanjem/404932, 18. 11. 2016.

27. T. H., 2014. Nekateri vojaki v socialni stiski, odločajo se tudi za osebni stečaj. http://www.rtvslo.si/slovenija/nekateri-vojaki-v-socialni-stiski-odlocajo-se-tudi-za-osebnistecaj/328414, 18. 11. 2016.

28. UMAR. 2013. Delovna projekcija prebivalstva Slovenije. http://www.umar.gov.si/fileadmin/ user_upload/sporocila_za_javnost/2013/november/projekcije_prebivalstva.pdf, 7. 4. 2017.

29. United States Census Bureau. U.S. and World Population Clock. https://www.census.gov/ popclock/?intcmp=home_pop, 7. 4. 2017.

30. Vlada Republike Slovenije. 2016. Srednjeročni obrambni program Republike Slovenije 2016-2020. http://www.mo.gov.si/fileadmin/mo.gov.si/pageuploads/pdf/ predpisiobramba/ SOPR2016 2020.pdf, 20. 12. 2016.

31. Walker, D., 2014. Trends in U.S. Military Spending. http://www.cfr.org/defense-budget/ trends-us-military-spending/p28855, 12. 12. 2016.

32. Young, Thomas-Durell. 2016. Izziv za obrambne reforme v srednji/vzhodni Evropi: primer Slovenije. V Sodobni vojaški izzivi, 4 (18), str. 15-34. http://www.slovenskavojska.sil fileadmin/slovenska_vojska/pdf/vojaski_izzivi/2016/svi_18_4.pdf, 5. 4. 2017.

33. Zorko, U., 2004. Obrambni izdatki Republike Slovenije v luči vključevanja v zvezo Nato. Ljubljana: Fakulteta za družbene vede. http://dk.fdv.uni-lj.si/dela/Zorko-Uros.PDF, 13. 12. 2016.

34. Žabkar, A., 2003. Marsova dediščina. Ljubljana: FDV.

35. Žabkar, A., 2004. Marsova dediščina, 2. knjiga. Ljubljana: FDV.

36. Žurga, V., 2016. Nova sodobna grožnja nacionalni varnosti-proračunska grožnja. V Sodobni vojaški izzivi, 4 (18), str. 35-50. http://www.slovenskavojska.si/fileadmin/ slovenska_vojska/pdf/vojaski_izzivi/2016/svi_18_4.pdf, 5. 4. 2017.

37. Žerjavič, P., 2015. Izdatki za obrambo: Slovenija čedalje bolj na muhi Nata. http://www. delo.si/novice/slovenija/izdatki-za-obrambo-slovenija-cedalje-bolj-na-muhi-nata.html, 17. 11. 2016. 